\title{
INTEGRATED TEACHING - A PROJECT IN PRIMARY SCHOOL ELECTIVE ART CLASSES
}

\author{
Zlata Tomljenović, Master of Art \\ Fakulty of Education, \\ University of Rijeka (Croatia) \\ e-mail: zlatatomljenovic@gmail.com \\ Svetlana Novaković, $B A$ \\ Fakulty of Education, \\ University of Zagreb (Croatia) \\ e-mail: snovakovic@vusp.hr
}

\begin{abstract}
A b s tract
Contemporary educational concepts advocate for interdisciplinary/integrative approach to teaching in order to generate operable knowledge applicable in life situations, as opposed to the mere memorizing of facts. Project teaching that is based on research and dealing with concepts within different subjects and disciplines as well as detecting and resolving problems through students' independent research work is one of the forms of integrated teaching. This paper presents theoretical background of integrated/project teaching and two examples of implementing project teaching during elective art class in the higher grades of elementary school as an alternative approach to teaching, which is in the contemporary school practice expected to carry out experiential and problem solving learning, as well as encourage independence and active participation of students. The results of implementing projects in art classes indicate a greater student motivation for work, developing social skills and self-confidence, active participation in the teaching process in addition to better quality and long-term acquisition of knowledge, skills and attitudes.
\end{abstract}

Keywords: project teaching, integrated teaching, constructivism, art classes, teaching strategies, elective class, correlation, interdisciplinary approach

\section{Introduction}

Knowledge production so far has resulted in its differentiation into numerous scientific disciplines and fields, and consequently the fragmentation of that knowledge. Contemporary times in which we live simultaneously require integration of knowledge, both on the global and educational level. The segmentation of 
information into sections within individual school subjects not only hinders the process of acquiring quality knowledge, but also its effective implementation in a wider social context. Knowledge that is specialised, separated according to various professions and so restricted that it tends to disintegrate the wholeness of the world, belongs to the past, and is becoming increasingly less understandable, acceptable or useful to the students (Polić, 2005). The objective of learning has become to develop integral knowledge applicable to everyday life situations, which inevitably imposes on the school educational system the need for integrating and connecting partially acquired knowledge within individual subjects and its presentation to the student in a clear, interesting and understandable manner. Specifically, problem-solving in real life situations does not require "knowledge learned from books" but integrative and interdisciplinary thinking.

Integrated teaching (correlation, thematic or project teaching) is more effective than the traditional ways of teaching since the student explores a phenomenon or a problem, observing them from different perspectives and connecting different areas of knowledge, while being an active participant in all the stages of the teaching process. In this way his or her knowledge becomes more permanent and more applicable in different life situations. Classes must be organized so as to offer a stimulating environment where students will be enabled to learn independently and responsibly, oriented towards action, spiritual and physical work as well as using all the senses. The most unrestrained form of integrated teaching is project teaching and its synonymous concept - the project method which has been used within reform pedagogy since the beginning of the 1970s. Project method enables the realization of the integrated approach to the teaching content through active learning based on personal experience. In project teaching all the students' potential can be activated, and teaching does not imply merely theoretical, but practical work as well. The importance of becoming involved in the practical process as an invaluable component, not only of educational subjects in school, is highlighted by many educational theorists (Meyer, 1987, Matijević, 2010, Silov, 2007). By engaging not only heads, but also hearts and hands, i.e. all the senses, the student acquires knowledge in an integral and most natural manner. Practical and creative work allows students to express themselves both verbally and nonverbally in a more relaxed atmosphere, thus enabling them to develop abilities and skills and develop awareness of their personal preferences and interests.

Because of its dynamic and practical nature, art classes are a good starting point for organising integrated/project teaching. Due to its universal visual language, it easily corresponds to the contents of other subjects. As such it offers a rich potential for the realization of contemporary didactic concepts that support and advocate independent, active, collaborative, problem-solving and experiential learning. Through modern forms of teaching students connect the knowledge of art concepts with their own practical work and experience using art techniques and materials. In this way, they develop artistic skills, knowledge and abilities and trigger emotional, psychomotor and affective features through independent art activity (Tacol, 2003). Through various integrating forms of work, interdisciplinary potential of the arts as a school subject is used in an appropriate way, the importance 
of the integration approach and the correlative possibilities within this subject and other subjects is emphasized, and the content of teaching is associated with life context with the aim to use knowledge practically and gradually shape a child's whole personality.

\section{Theoretical basis of integrated teaching}

Different forms of integrated teaching have emerged in the late 19th century, however, the one thing they all have in common is the emphasis on the need for students' active role in the construction and acquisition of personal knowledge that would be connected to the realities of life. Authors of new directions in education were philosophers and pedagogues, J. H. Pestalozzi, F. Froebel, J.F. Herbart, W. James and J. Dewey (Čdina-Obradović, 2009). The first person to introduce the project method into teaching practise as a form of integrated teaching on the theoretical basis of pedagogical pragmatism was its founder J. Dewey. W. H. Kilpatrick and E. Collings are the most deserving for its further development. Pedagogy of pragmatism emphasises the value of knowledge based on the students' individual capabilities and personalities, built on experiential learning in real life situations. Students are at the centre of the teaching process and, because their learning comes through personal experience, they are the instigators of their own education. Dewey considered the power of thought to be in acting, therefore, in the project method he especially emphasised students' activity and the encouragement of development of permanent interests (Špoljar, 2004). According to Dewey, children's innate interests represent the need to communicate and socialize, work, explore and express themselves through art. According to these interests and personal preferences, students choose the problem; they investigate and solve it together with other students, thus forming preconditions for the creation of integrated knowledge and its application. Project method was developed as a reaction to traditional frontal teaching divided into strictly separated subjects, with a tendency toward integrated learning through topics or problems that students select independently according to their interests and capabilities, independently search sources of information and determine the scope, depth and difficulty of the research problems as well as the pace of progress.

During the 1960s and 1970s educational theorists and practitioners have become aware of the deficiencies of frontal teaching so they turned to teaching and learning methods developed in the spirit of constructivism. Constructivist theory again brings the students to the forefront, that is, it builds on the ideas of J. Dewey, M. Montessori and C. Freinet, the founders of the student-centred didactics (Matijević, 2010). The term constructivism refers to the theories of knowledge, and learning theories derived from them and based on the assumption that knowledge is a human construct emerged as a result of the individual and wider social reality (Plut-Pregelj in: Marentič Požarnik, 2004). In educational terms, constructivism represents a way of thinking about knowledge/cognition on which a model of learning and teaching as well as curriculum is built with the intention of improving the quality of education, where students play an active role in creating their own 
knowledge (Daugiamas, 1998). The beginning of the creation of modern/ constructivist concepts in pedagogy can be recognized in the theories of J. Piaget and L. Vygotsky who explain learning as an active student experience that occurs in interaction with social environment. K. Reich (Reich, 2006) advocates for the interactionist constructivism and describes it as a reconstruction (discovering the world), construction (creating the world) and deconstruction (criticism of the world), with these constructivism being connected with action and doing of the learner. The subjective experience is always in relation to socio-cultural environment in which learning takes place. The role of the teacher in the constructivism does not consist of knowledge transfer, but in providing advice, support and encouragement for independent activity of students who must consolidate the existing knowledge, continue to shape it in accordance with previous experience, their own characteristics and surroundings, so that through abstraction they can reach higher levels of cognition.

Basic principles of constructivism according to J.G. Brooks and M. Brooks (in Čudina-Obradović, 2009) are active participation and interaction of teachers and students in the process of knowledge creation, student collaboration, teachers' and students' contemplation about the process of learning, teaching and results (reflexive pedagogy), investigative learning and enrichment of knowledge through new experiences. According to constructivist theory, knowledge is generated through students' self-activity in the process of problem solving, designing concepts and verifying their validity. In the process, the teachers' role is also changing and they are no longer transmitters of knowledge but creators of a stimulating environment and providers of the conditions under which knowledge is generated.

According to the principles of constructivist theory, all teaching methods are good, as long as they encourage active and constructive learning processes. Taking into account the different perspectives of knowledge, constructivist principle not only enables, but also emphasizes the need for different ways and forms of teaching and learning, especially those which place an emphasis on learning through practice and personal experience, like project teaching does.

\section{Project teaching and project method}

Project teaching is one of the forms of integrated thematic teaching (ČudinaObradović, 2009) where concepts are explored and dealt with in different subjects and disciplines. In the project teaching content itself is not as important as the concept of learning based on the students' independent research work (Bognar, Matijević, 2002). An important feature of project teaching is that students are active participants in the entire teaching process, from the selection of the topic or problem they want to solve, choice of the methods and data collection procedures, data processing, problem solving and presenting the obtained results. In this way students experience more freedom and responsibility and in addition intrinsic motivation is encouraged. The project method takes students' individual differences and capabilities into consideration. Since the beginning of the work on a project till its 
completion, each student selects the contents, sources of knowledge, the width and the depth of dealing with the problem in accordance with personal cognitive potential thus affecting the pace of one's own progress. Each project represents the exploration of a certain social problem that is interesting and unknown to the students, that is being solved in collaboration and produces the result important to all the project participants (Meyer, 2002). Project research is suitable both for preschool children as well as for all elementary school children. The number of participants in a project can vary from the whole class, a group of students or individual participants.

The project method is suitable for elective classes, extracurricular activities or as additional work for gifted and talented students. The project topic can be any problem stated in the curriculum or some other topic which students find to be motivating and interesting. The teacher is the one directing how difficult the task will be according to student's individual capabilities and possibilities and helps them with defining the project problem itself.

According to the degree of students' independence in topic selection, defining the methodology for data collection and processing, providing work material and means, project tasks can be divided into structured or unstructured (Gudjons, 1986; in Blažić, Milić, 2005). In the project teaching all work stages are planned and objectives determine the place, duration and material means necessary for the project creation. K. Frey (Frey, 1995) sets five stages in the project creation: initiative, project sketch, realisation outline, execution, final stage. Gormaz (2006) states the following stages of project teaching: 1. Finding project topic, 2. Formulating research problem, 3. Planning and defining work tasks for groups and individuals, 4. Project execution - research, 5. Comparison of collected information, inventory, evaluation, naming open questions, 6. Formulation of results (transformation and application), 7. Results presentation, 8. Reflection on the project-control of the learned subject matter and evaluation. Depending on the complexity of the project problem, project work can last a few days, weeks, months or entire school year. The project work result is not merely gaining knowledge, but also the creation of a product. The final product is equally important as the process itself (Gudjons, 1994). It can be an exhibition, a picture book, sculpture and installation, play, puppet play or a report on the work results. Presentation of the project enables students to discuss the project, produce new ideas for its improvement or creating a new project and critical review of the value of their own work.

Teaching strategies and methods used in the project teaching need to offer opportunities for learning and teaching through immediate connection with the environment in which students can participate, and can use and modify it as needed. Due to the complexity of performing project teaching, activities planned by the teacher must be elaborated in detail, and the objectives have to be clearly defined. That does not mean that the teaching environment must be strictly structured, just the opposite - there is a tendency towards students' free expression without excessive management and control during the teaching process. 
The objective of project teaching is achieving greater student independence and initiative in mastering planning strategies, using sources, data analysis and problem solving, as well as developing collaborative relations among students and between students and teachers. Through collaboration with other students in working on the project, communicative and cooperative skills and skills of accepting and respecting the opinions of others are developed. Furthermore, students gain selfconfidence and sense of security in dealing with everyday life problems and consequently they become ready for independent management of their own learning process and representing their own opinion. Knowledge is built upon previous experience and gradual adoption of factual and procedural knowledge through data collection and systematization through conceptual knowledge (data processing) to knowledge implementation. This form of integrated teaching enables students to fully grow in cognitive, affective and psychomotor areas.

\section{The roles of the teacher and the student in project teaching}

While in traditional teaching, the role of the teachers was to transfer knowledge, in project teaching their role is to provide a stimulating environment where students will be able to learn independently and actively. The teacher helps students define the problem; find the venue, expert assistants, materials and means; and to organize team work. This new role of the teachers in the classroom requires solid didactical and methodical knowledge, understanding contemporary teaching strategies, as well as communicational and organisational skills important for team work. Therefore, in project teaching, the teacher is a mentor who organises independent and collaborative students' work (Razdevšek-Pučko, 2005). They also act as coordinators, who manage the process from the background and encourage students in their dialogue and integration of the content from different sources and correlating the acquired knowledge. Teachers also need the knowledge in the field of psychology, especially for determining the difficulty of the research problem with respect to cognitive and motivational abilities of students. Therefore, they need to know each student in order to be able to adjust their teaching to the students' individual cognitive abilities and learning styles for the students to be able to acquire more knowledge and be more successful in learning. Due to the flexible organization of this type of teaching, the teaching content, teaching methods and objectives can be tailored to each student. Individual work affects student motivation for independent and creative expression. Both teacher and students in integrated classes reflect on the quality of work processes and the achieved results (reflectivity).

In project teaching each student is an active participant who takes the initiative and responsibility for his/her learning. The starting point of student's activity is thinking about the problem and asking himself/herself and others questions, discovering one's own background knowledge, deciding on the methods and forms of work with further development of the activity through independent problem solving. Student is free to choose the source of information, the procedure for solving the tasks and presenting solutions. In defining and solving the problem, 
students use their prior experience on which they build upon using new knowledge. In addition, student develops social skills by communicating and collaborating with others in the group. He/she appreciates his/her own opinion but also respects the opinion of others while trying to define and solve the problem, and verify joint results. Project teaching enables students to discover individual interests, abilities and talents and instigates intrinsic motivation for active work participation.

\section{Advantages and disadvantages of project teaching}

In project teaching student is an active participant in all the work process stages thus developing personal autonomy and responsibility. Knowledge gained by learning in this way becomes more permanent and more applicable. A student develops higher thought processes such as analysis, synthesis and evaluation, critical and logical thinking. He/she also acquires independent learning skills, the results of which are increased self-confidence and greater work motivation. Independence can be seen in the abilities to perceive the problem, ask questions, independently devise the work plan, process the data and solve the problem. Such teaching enables interdisciplinary approach to the learning content. The advantage of project teaching is also unlimited project duration and the place of work on the project can be in school or outside of it (in a museum, library, outdoors...). The importance of integrated learning and project teaching results from the new role of the school which has to «provide the possibility of experiences which surpass intellectual learning and encourage students' integral developmental process» (Terhart, 2001:183).

Project teaching is more extensive, wider and more demanding form of educational work whose implementation requires more time. Difficulties in organising project teaching come from increased expenses of teaching materials and means in addition to temporal discrepancies with the obligations in regular classes. Non-implementation of project teaching may also stem from the lack of motivation among teachers resulting from various constraints such as inadequate material and technical conditions in schools, lack of time, lack of support in school. Ideal organisational frame for implementing projects are elective classes which have a more flexible time frame and where the teaching contents are expanded outside of the given curriculum, according to students' interests and abilities.

\section{Project and teaching art}

The main task of teaching art is developing students' creativity in art through independent artistic expression and research, through respect for their spontaneous perception and creation as the basis for developing students' autonomy and individuality. The foundation of artistic expression is precisely the experience of students with the help of which students interpret and reinterpret the visible individual experience of the world that surrounds them. Contrary to traditional teaching methods, project teaching enables experiential and investigative learning 
that leads to the integration of content from different areas, and a deeper understanding and application of knowledge. Working on the project, students have an active role in all stages of the project, and simultaneously have an opportunity for comprehensive personal development. Class activities connect students' emotional, aesthetic and social development with an independent artistic expression, acquisition of art concepts and principles of art (Tacol, 2004). Students independently plan the course of the entire activity: they acquaint themselves with and develop an awareness of the art problem, they solve the problem, shape the immediate experience that they analyze, evaluate and assess. Project teaching emphasizes the individual approach that allows each student to develop within their capabilities (Agirre et al, 2004). Solving art problems using experiential learning, students formulate their own standpoints, and express their desires and interests.

Project teaching requires art teachers to be prepared for an interactive teaching approach in which the student has an active role. What is needed is good communication among all the participants in the teaching process, with the teacher recognizing the student's artistic abilities, his/her initiative and his/her own solutions because art teaching is individual in its basis as it stems from the needs and sensitivities of each student (Berce-Golob, Karlavaris, 1991). The teacher's role is simultaneously that of an organizer, mentor, partner, associate and coordinator of the creative teaching process where the students will, through artistic expression, acquire art concepts and connect them with other subject areas. In teaching, the teacher directs students' attention to certain features of art motifs or techniques; directs the conversation so that students themselves discover and become aware of artistic elements and their relationships, encourages students to independent research, activities and creative expression; directs the conversation, encourages dialogue and discussion about fine art and thereby helps in shaping the criteria for their evaluation; acts in such a way that art experience and personal creative work are preserved in the minds of students as an art experience. It is the responsibility of teachers to structure their teaching so that students can upgrade the appropriate cognitive framework for learning how to learn in the fine arts (Cunliffe, 1999). The atmosphere created by the teacher must be such that the students can spontaneously and freely express their thoughts and feelings, expand their horizons and connect separate areas of knowledge.

The implementation of project teaching in art classes seeks to encourage the development of visual thinking and other perceptual and cognitive abilities, especially the ability of active observation, visual memory, fantasy, combinatorics, fluent and divergent thinking, critical assessment, creative expression, evaluation and conclusion. On the other hand, there is a tendency to create conditions for a relaxed, flexible and active teaching environment where a positive working atmosphere and communication links between students and teachers can be created with the aim to facilitate the development of voluntary and emotional characteristics of students, affective experience, identification with art/aesthetic and ethical dimensions of the available content.

Elective art classes ensure that the contents planned in the curriculum (whose quantity does not generally decrease with decreasing the number of regular art 
lessons) can expand in a variety of creative ways that emphasize students' independent and creative activities. During elective classes students are enabled to acquire additional knowledge, skills and abilities within the field of fine arts, as well as the ability to link the acquired knowledge with the teaching content in other subjects. Elective classes, that is, extracurricular forms of organization give students a greater possibility to implement contemporary methods of work such as problem solving, experiential, investigative, independent and active learning. In addition, they offer more freedom in planning and implementing teaching, whose performance will largely depend on the professional, expert and personal competence of teachers and the motivation, enthusiasm and ability to convey those traits to students. This paper will present two models of project teaching in elective art classes, whose concept and structure present one of the possible innovative teaching approaches, whose form and structure present one of the alternative approaches to teaching which are in the contemporary school practice expected to carry out experiential and problem solving learning, as well as encourage independence and active participation of students in the learning process.

\section{Project "Glagolitic script - a picture in words, a word in a picture"}

The project Glagolitic script - a picture in words, a word in a picture has been implemented in the elementary school "Škurinje Rijeka" in Rijeka in the academic year 2007/2008 with the aim to update the strategies for working with students in regular and extracurricular activities through correlation/integration of the following school subjects: Croatian language, history and art classes. The thematic framework of the project was the Glagolitic script as an important segment of Croatian non-material heritage. The project was implemented as part of elective art classes in addition to the regular and additional Croatian language and history classes in the seventh grade (elementary school). When choosing the project task, students' abilities and capabilities, needs, interests and desires were considered. Project planning included the motivation of students through a discussion of the suggested topic, content processing abilities, students' expectations from such work, purposefulness of the project, time restrictions for individual stages and the material conditions for the realization of specific ideas. The teachers' task during the planning stage consisted in adapting the didactic and methodical procedures to the specific characteristics of individual subjects and to various stages of work.

The first stage of the project included the introduction to the topic from the aspect of history, literature, linguistics and fine arts. At this stage integrated teaching of Croatian language and art was carried out (the historical context of the emergence and development of Glagolitic script was taught separately during additional classes in history, due to inability to harmonise timing of the lessons). After preparing students for the chosen topic, students were divided into groups and each group was given a task. The implementation of the plan for this project also included field work, i.e. a visit to the permanent exhibition "Glagolitic script" in the Rijeka University Library, which has a display of the Glagolitic heritage of the Croatian people in one place and also has, methodically presented, the development of 
Glagolitic script historically, geographically and in the human environment. As part of their additional Croatian language and history classes, students conducted independent research through the collection, analysis, selection and systematization of the historical, linguistic and pictorial material relating to the Glagolitic script. One group of students used the collected material to create posters within the three subtopics (Illumination in Glagolitic inscriptions, Glagolitic inscriptions in stone, Written and printed Glagolitic script in texts); the second group of students were engaged in writing their own stories in Glagolitic script and binding them into a book-a picture book; the third group of students used dramatization, i.e. movement and stage play to visualize the content of the stories. During elective art classes, students made sketches for Glagolitic letters while the second stage of work included the modelling of ceramic reliefs depicting the Glagolitic alphabet. At the end, evaluation of the results and analysis of the overall activities of the project was conducted within the integrated teaching of all three classes. The project was presented in the exhibition of students' work at school. After that, the art exhibition entitled "My beautiful region" was presented to the general public in the gallery "Kružna" in Rijeka, where, in addition to the relief depicting Glagolitic script, there was ceramic art work inspired by material and non-material cultural heritage of the coastal region.

The time planned for the realization of the project within elective art classes was one school year, of which two months were scheduled for the realization of the first part of the project, and six months for the realization of the second part- making of a ceramic relief. The objective of art classes was to produce square ceramic reliefs of individual Glagolitic letters in the ceramic technique to be used in a wall frieze. The purpose of the placing on the wall of the school hallway was to emphasize the physical connection between three subjects that correlated in this project. Due to the technical complexity of relief making, the teaching was divided into several stages. In the first stage the students were introduced to the Glagolitic script, they were supposed to recognize its visual and artistic features, and study different ways of decorating/illuminating letters. Afterwards, the students selected, at their own discretion, several Glagolitic letters that were drawn and artistically enriched through their own interpretation of the seen material. Through a joint discussion with the teacher they selected the best works of art that were taken as a template for the following stage of work - transferring the drawings onto the plasterboards and carving them. The teacher approached this challenging task by working individually with each student and by being present at every stage providing advice and technical assistance. This was the first time the students met this kind of modelling that is long-term and requires attention, motor skills and much effort, and as such is not suitable for presentation in the regular classes. After developing the negatives, previously rolled flat clay tablets were impressed into them thus producing clay letter reliefs, which were dried and processed using the usual technological process for making ceramics. By setting a definite objective (decorating the school hall), students were given a specific sense of usefulness and meaningfulness of their work. The exhibition presented the results of the students' work to the public and the 
contents of the curriculum were used as a contribution to the enrichment of the social and cultural life of the community.

With project teaching, the multiple correlation of teaching content was achieved on thematic and structural, as well as horizontal and vertical level. Thematic correlation was achieved using the topic of Glagolitic script divided into specific teaching units within all three subjects (Croatian language: Glagolitic script, Learning the terminology for the specific Glagolitic letters, Mastering writing in the Glagolitic script, Comparing this script with the alphabet and other scripts, Old Church Slavonic language; history classes: Determination of and learning about the time frame in which the Glagolitic script occurred; art classes: Graphic expressiveness of the letters and inscriptions, Artistic value of the Glagolitic script, Visual communications - transmitting messages in pictures and words). Structural correlation was achieved through introduction/elaboration of the terms: rhythm, progress, decoration, expression, dominance, composition, cycle, script. The horizontal correlation was conducted by linking the content of these three subjects, planned for the seventh grade, but also within the art class by combining different teaching topics (The rhythm of structural and contour lines, The complex rhythm of the composition, Linear complex structures, Balance and rhythm in the art composition, Line and graphic expression of letters and inscriptions).

As part of elective art lessons, workshop type of classes was applied as the appropriate form of teaching strategy that would guarantee cohesion between theory and practice, create favourable working environment and activate all students in class-related activities.

The objective of the project teaching in art classes included the development of knowledge, skills and attitudes through accomplishment of educational, and art assignments. Educational tasks referred to: exploring the Glagolitic script, identifying links between pictures and letters - realizing that messages can be transmitted using visual means, in addition to the development of students' cognitive, expressive, experiential, creative and motor skills; creating a positive attitude to the aesthetic values of personal artwork and works of art, and becoming aware of the need to preserve cultural heritage.

Art tasks were related to: recognizing artistic features/values in the observed shapes (Glagolitic letters, illuminations, stone monuments written in Glagolitic script, frescoes), understanding the use of ornaments in the Glagolitic script; identification, recognition and adoption of elements of art and their relationships within the composition, learning about and mastering the techniques of making ceramics and ceramic relief impression in the negative, observing the principles of creating form and technological demands of the materials in question, as well as understanding of their own three-dimensional tactile and formative research through formative work. 


\section{The project "Shape and space in creating dishes - traditional artefacts of our region"}

This project was developed as part of a broader study of the role of museums in art education, with the aim of introducing students to cultural heritage through immediate contact with the museum exhibits. The project included the organization of thematic art workshops in the museum and the presentation of student works to the wider community by staging the exhibition in the museum. The participants in the project were fifth and sixth grade elective art class students attending elementary school Viktorovac in Sisak in the school year 2007/2008. As part of the curriculum of the elective art class, the students, accompanied by their teacher, visited the Sisak City Museum, and were acquainted with its permanent exhibition: the archaeological collection of prehistoric artefacts, archaeological collections of the medieval artefacts, ethnographic, numismatic and historical collections covering the period from 13th to 20th century. Students showed considerable interest in the ethnographic collection and expressed a desire to further explore traditional crafts, creation of the old clay pottery and the practical value of individual artefacts.

Within the elective art classes, the theme of the project was chosen and a detailed work plan was prepared as a result of the collaboration between students and teacher. The project lasted for two months with the majority of activities taking place in the museum. Katica Mrgić, senior curator of the ethnographic collections, introduced the students to the traditional crafts, historical development and method of making pottery items made of clay that were used in the household. During elective art lessons, directed in their observation of sculptures, the students noticed, compared and adopted different ways of modelling in clay with regard to the relationship of mass and space, adopted the basic knowledge about clay (modelling mode, types of clay, preparation and drying of clay, baking and glazing ...) and made sketches for their dishes. Next, the students were divided into two groups, with each group receiving their research assignments. Some noted the information listed below the exhibits in the museum and sought detailed descriptions of the archaeological site and methods for ceramic making process in the catalogue and books they found in the museum, while others talked with the museum curator, who introduced them to the practical value of individual items, the traditional methods of making dishes before the invention of the potter's wheel, the method of baking clay and division of pottery products with regard to the pottery making technique. During data collection, students used the following research methods: observation, data recording, analysis and practical work. After an independent data collection and processing, during which they acquired new knowledge and created posters, in the museum workshop the students explored and modelled in clay, thus solving art problem in the field of three-dimensional modelling by making their dishes from a mass (a ball) or using a succession of strip shapes.

The teacher's role in the project consisted of organizing museum visits, consultations with the curator-educator, introducing students to the museum as an institution and visiting the permanent exhibition at the museum, introducing students 
to the tasks that would be accomplished during art workshops at the museum, additional stimulation of the students during their creative work in the workshop by asking alternative questions and giving technical advice. The final part of the project included a discussion of the work results, evaluation and the presentation of the project. At The City Museum Sisak, students staged an exhibition of their works of art presenting their project to the wider community.

The project objective was to develop beliefs and attitudes in the scope of art reality, the evaluation of the content and ideas, developing research curiosity through creative work in the museum workshops, introduction to cultural heritage, developing visual perception, visual thinking and producing works of art. General educational objectives related to the recognition, identification, differentiation and application of knowledge, developing creative thinking, discovering the aesthetic values of different ways of shaping the traditional objects, developing a positive attitude towards cultural heritage, fostering independence, perseverance and consistency in work, respect for their own and other people's opinions and work, developing collaborative relationships. Art tasks of the project were: the acquisition of art concepts by observing, comparing, understanding and evaluation of artistic elements in the works of art and personal art work as well as practical work in making a clay dish.

\section{Conclusion}

The introduction of the new teaching strategies, forms and methods of work aims to inspire students to reflect on what they are learning, and show them how to best use the gained knowledge and experience in everyday life. Bruner (Bruner, 2000) stated that the educational process must lead to understanding, rather than passive acquisition of knowledge, and it will be most useful to the student if acquired through personal cognitive efforts, or if it becomes part of his/her personal experience. One of the main objectives of integrated instruction in the educational process, as well as in art classes, is to establish student knowledge, skills and attitudes so that they become useful and applicable in a wider social context rather than merely school context.

With the structure which is more demanding than those utilised in the regular teaching, the project also imposes the application of specific teaching strategies that involve a more active approach to teaching content than the usual regular teaching, establishing a correlative relationship with other subjects, i.e. interdisciplinary approach to a teaching assignment, teacher teamwork, encouraging active, investigative, problem solving and experiential learning; in other words acquiring knowledge through personal experience and engagement. These requirements impose the use of those methods that allow and encourage the implementation of the aforementioned activities (research methods, discussion, dialogue, problem solving, interpretation, redefining the problem/using the content in new ways, methods of active experience, creative play, etc.). 
These examples of project teaching in art classes indicate positive reactions of students relating to interdisciplinary/integrated approach to teaching; teaching is more interesting, comprises more challenges and possibilities for everyone to find the content for active processing that suits them the best. The results also indicate a greater student motivation for work, acquiring social skills through group and team work, active participation in the teaching process, better quality and long-term acquisition of knowledge, skills and attitudes that are constructed/upgraded due to students' own efforts, research and understanding through active approach to the teaching content and practical work. Implementation of the project task inspired in students the stimulation of perceptual, volitional and intellectual abilities through searching for the links in different subjects and contents; strengthened the confidence because of the acquisition of new knowledge, abilities and skills and because of creating specific products that will be applicable; it inspired the development of curiosity and motivation for successful realization of the tasks through problem solving approach to teaching and practical work with art materials.

Student satisfaction with the work, intrinsic motivation and creativity are the indicators of the adequacy of the planned tasks, the applied methods and approaches to learning and teaching, as well as further guidelines in planning future learning activities.

\section{Bibliography}

Agirre, I., Marcellan, I., Vidador, M. i Arriaga, A. (2004). Rad kroz projekte i istraživanje kao motivacijski put u umjetničkoj edukaciji: naše iskustvo $s$ umjetničkom zbirkom Javnog Sveučilišta u Navarri. In: Aktualne teme, dimenzije, perspektive in dileme motiviranja otrok, učencev in mladine pri izvajanju likovnih dejavosti v vrtcu in pri pouku likovne vzgoje in likovne umetnosti, 1. Mednarodni kolokvij o motivaciji pri pouku likovne vzgoje in likovne umetnosti, Škofja Loka, Slovenija, 2.-4.oktober, str.16-17.

Beckett, G. H. (2002). Teacher and Student Evaluations of Project-Based Instruction. In: Tesl Canada Journal/Revue Tesl du Canada, Vol. 19, br. 2, str. 52-66.

Berce-Golob, B., Karlavaris, B. (1991). Likovna vzgoja. Priročnik za učitelje razrednega pouka. Ljubljana: DSZ

Blažić, M., Milić, I. (2005). Projektni rad i samostalnost učenika. In: Pedagoška obzorja, br. 3-4, 2005., str.28-50.

Bognar, L., Matijević, M. (2005). Didaktika. Zagreb: Školska knjiga

Bruner, J. (2000.). Kultura obrazovanja. Zagreb: Educa

Cunlife, L. (1999). Learning How to Learn, Art Education and the „Background“. In: Journal of Art and Design Education, Vol. 18, br. 1, 1999., str. 115-121.

Čudina-Obradović, M., Brajković, S. (2009.). Integrirano poučavanje. Zagreb: Biblioteka korak po korak

Desforges, C. (2001). Uspješno učenje i poučavanje. Zagreb: Educa

Frey, K. (1995). Die Projektmethode. Weinheim: Beltz Verlag 
Gormaz, J. (2006). Izazovi HNOS-a: projektna nastava u vjeronauku. In: Crkva u svijetu, br. 41, 2006., str.166-192.

Gudjons, H. (1994). Pedagogija- temeljna znanja. Zagreb: Educa

Krauth, G. (1985). Leben, Arbeit und Projekt: Eine konzeptionsgeschichtliche und vergleichende Studie über die gesellschaftliche, pädagogische und didaktische Bedeutung der Projektidee in reformpädagogischen Bewegungen. Frankfurt: Lang.

Kyriacou, C. (2001). Temeljna nastavna umijeća. Zagreb: Educa

Matijević, M. (2010). Između didaktike nastave usmjerene na učenika i kurikulumske teorije. In: Zbornik radova Četvrtog kongresa matematike. Zagreb: Hrvatsko matematičko društvo i Školska knjiga, str. 391-408.

Meyer, H. (2002). Didaktika razredne kvake. Zagreb: Educa

Meyer, H. (1987). Unterrichtsmethoden II. Berlin: Connelsen Verlag

Plut Pregelj, L. (2004). Konstruktivitične teorije znanja in šolska reforma: učitelj v vlogi učenca. In: Marentič Požarnik, B. (ur.). Konstruktivizem v šoli in izobraževanju učiteljev, konferenčni zbornik, 2004., Ljubljana: Center za pedagoško izobraževanje Filozofske fakultete, str. 17-40.

Polić, M. (2005). Integralna nastava kao odgovor na suvremene obrazovne potrebe. In: Metodički ogledi, Vol. 12, br 2, 2005., str. 61-72.

Razdevšek-Pučko, C. (2005). Kakvog učitelja/nastavnika treba (očekuje) škola danas (i sutra)?. U: Napredak, Vol. 146, br. 1, 2005., str. 75-90.

Reich, K. (2006). Konstruktivistische Didaktik - ein Lehr- und Studienbuch. Weinheim: Beltz-Verlag

Silov, M. (2007) Odgoj i teorija smisla. In: Odgojne znanosti, Vol. 9, br. 1, 2007., str. 7589.

Špoljar, K. (2004). Pedagoški konstruktivizem v teoriji in vzgojno-izobraževalni praksi. In: Marenič Požarnik, B. (ur.) Konstruktivizem v šoli in izobraževanje učiteljev, konferenčni zbornik, 2004., Ljubljana: Center za pedagoško izobraževanje Filozofske fakultete, str.63-68.

Tacol, T. (2003). Likovno izražanje. Didaktična izhodišča za problemski pouk likovne vzgoje v devetletni osnovni šoli. Ljubljana: Debora

Tacol, T. (2004). Učitelj - snovalec ustvarjalnega učnega procesa likovne vzgoje. In: Marenič Požarnik, B. (ur.). Konstruktivizem v šoli in izobraževanje učiteljev, konferenčni zbornik, 2004., str. 397-410., Ljubljana: Center za pedagoško izobraževanje Filozofske fakultete

Terhart, E. (2001). Metode poučavanja i učenja. Zagreb: Educa

\section{Internet sources:}

Dougiamas, M. (1998). A Journey into Constructivism. http://douigamas.com/writing/ constructivism.htlm, 15.10.2010. 
Metodički obzori 7(2012)1

Pregledni rad

UDK: $371.3: 373.3$

Primljeno: 20. 8. 2010.

\title{
INTEGRIRANA NASTAVA - PROJEKT U IZBORNOJ NASTAVI LIKOVNE KULTURE U OSNOVNOJ ŠKOLI
}

\author{
Mr. art. Zlata Tomljenović, \\ Učiteljski fakultet, Sveučilište u Rijeci (Hrvatska) \\ e-mail: zlatatomljenovic@gmail.com \\ Svetlana Novaković, prof. \\ Učiteljski fakultet, Podružnica Petrinja, \\ Sveučilište u Zagrebu (Hrvatska) \\ e-mail: snovakovic@vusp.hr
}

\section{Sažetak}

Suvremeni pedagoški koncepti zalažu se za interdisciplinarni/integrativni pristup poučavanju u svrhu generiranja operabilnog znanja primjenjivog u životnim situacijama, nasuprot pukom memoriranju činjenica. Jedan od oblika integriranog načina poučavanja predstavlja projektna nastava koja se zasniva na istraživanju i obrađivanju pojmova unutar različitih predmeta i disciplina te otkrivanju i rješavanju problema kroz samostalni istraživački rad učenika. U radu su prikazana teoretska ishodišta integrirane/projektne nastave te dva primjera provođenja projektne nastave u okviru izborne nastave likovne kulture u višim razredima osnovne škole, kao mogućih alternativnih pristupa nastavi od koje se u suvremenoj školskoj praksi očekuje provođenje iskustvenog i problemskog učenja te potenciranje samostalnosti i aktivnosti učenika. Rezultati rada u projektnoj nastavi likovne kulture ukazuju na veću učeničku motivaciju za rad, razvijanje socijalnih vještina i samopouzdanja, aktivno sudjelovanje u nastavnom procesu te kvalitetnije i dugotrajnije usvajanje znanja, vještina i stavova.

Ključne riječi: integrirana nastava, projektna nastava, konstruktivizam, likovna kultura, nastavne strategije, izborna nastava, korelacija, interdisciplinarni pristup 